\title{
Systems and techniques of administrative ommunication under the auspices of youth at Fayoum University
}

\section{Dr. Moataz Ali Hassan}

\section{Introduction and Research Problem:}

The communication process is an integral part of the work of any organization. The organization is an open system that affects and is influenced by the surrounding environment. No organization can live without contact or interaction with elements of the surrounding environment in order to preserve and sustain it.

Kamal al-Din Abdul Rahman Darwish and Mohamed Sobhy Hassanein (2004) note that since human existence on Earth, he has communicated with all around him through his senses in order to obtain information that helps him to understand the properties of objects and ways of dealing with them. In itself, communication is the cornerstone of human society. Without communication, society can not facilitate its daily affairs, nor can it change or transfer its heritage to future generations. (13: 143)

The communication process, according to Abdul Hamid Abdel Fattah alMaghrabi, includes: Sending,
Receiving and Interpreting Massages through sensory channels.

The main methods of communication with subordinates depend on verbal communication or non-verbal communication. (9: 58)

The process communication is one of the basic elements of human interaction. Through good communication systems, groups and organizations interacted and were able to make tangible progress in the economic, social and cultural development of societies.

At the same time, communication systems The failure has caused many social and economic problems in human societies throughout the ages. (8: 139)

He stressed that without communication there is no organization, communication is necessary to provide the information on which the decisions are based. On this basis, communication is an important and necessary factor in the process of guidance and 
the communication is the tool that connects all parts of the administrative system, both in the internal relationship or external

They are simple, direct and informal in organizations made up of a limited number of employees, but they become complex, formal and indirect in large organizations. Structured communication plays a very important role at present because of the multiplicity of administrative bodies and some of them Some of the other large spaces. (2: 150)

Communication plays a vital role in communicating opinions, ideas, information, perspectives and experiences among management and employees, influencing the behavior of individuals and groups, changing or modifying these behaviors and turning them towards a specific direction, and determining the manner and manner of dealing with each other to the degree that it can be said that communication Management is the heart of management in any organization $(14: 17,18)$.

The employees of the various establishments are the backbone of the internal audience of the establishment, and their success or failure depends.

Once the employer has been able to identify his workers, their wishes and needs, this process is now one of the most difficult because of the increasing size of the establishments and the numbers of employees. And the relationship between senior management levels and the working population was almost broken, resulting in a misunderstanding and misunderstanding of the nature and needs of the party to the other party $(4: 11)$

Communication in the organization is the vital nerve through which the institution operates, but it is rare for the management of the institutions to communicate in it, although its communicative tasks are essential and it is supposed to realize the importance of communication for human life and the life of its institutions and its interaction with the public.

Without effective communication, the organization can not succeed even if it has excellent strategies and wise plans. Therefore, senior managers are always focused on effective 
communications and skills as one of the important elements of the management process. (10: 53)

\section{Improving}

communications is a first-class administrative responsibility. In order for administrations to achieve this, they need to understand the nature of communication networks in their institutions, to determine the effectiveness of communication and the best means.

On the other hand, understanding the nature of the networks makes it easier for the caller to prepare his or her appropriate message to be more influential. Good communication provides an opportunity to identify the best choices and alternatives for making the right decision by integrating different information for better decision making. (8: 65)

The study confirms that the information and data is the heart of the administrative process, which is the essence of the work of the administrative leader in the facility and to the extent that this information and data accurate and correct, as far as the decisions of the director is effective.

Due to the importance of communication in managing the administration, there is a great need to organize and achieve its efficiency, so that the flow of information and data in a continuous movement between the levels of multiple organization in the best interests of the Organization and achieve its objectives. (1: 128)

" The presence of an effective communication network within the organization is one of the most important modern administrative systems. It connects the members of the organization and disseminates among them the facts, ideas and information clearly, thus providing them with a suitable environment for performing their work with satisfactory efficiency.

The work of any organization is based mainly on providing the correct data and information and exchanging it among the individuals and departments of the organization at different administrative levels, where communication is important and vital in providing the 
information on which decisions are based. (5: 91)

In the opinion of the researcher that in order to be the management of youth care at the highest level of administrative and technical can not be done only by knowing the positive and negative aspects and management in the process of communication within the Department of Youth Welfare and activate administrative communication.

The researcher noted that the Department of Youth Care lacks modern technological methods in communication processes that help to link and document the link to its departments, resulting in a communication gap between the Youth Welfare Department and its departments, in addition to many obstacles that limit the effectiveness of communication. Obstacles personal or private means used or regulatory or environmental, which drew the researcher's interest to identify the role of administrative communication systems and techniques in the development of the level of performance of the staff of the
Department of Youth Care Fayoum University.

\section{Research goals:}

The aim of the research is to identify the systems and techniques of administrative communication and its role in developing the level of performance of youth care workers at Fayoum University. Research Questions:

This research answers an important question:

-What are the components of administrative communication systems and techniques sponsored by young people at Fayoum University?

\section{Search terms:}

-Communication Techniques

Communication Techniques:

Tools, tools and advanced equipment that are used for the purpose of transferring information and data from the sender to the receiver in the least time, at the lowest cost and more accurately. " (24: 43)

\section{Research Methodology:}

The researcher used the descriptive approach (survey studies) to suit the nature and procedures of the research.

\section{Research community:}

The research community represents the staff (Director Generalof 
Department - Specialists) in the Department of Youth Welfare Fayoum University.

\section{The research sample:}

The random sample was chosen from the employees (general manager, director of department, specialist) at the Youth Welfare Department, Fayoum University.

Table (1)

Society and sample research

\begin{tabular}{|c|c|c|c|c|}
\hline Serial & Job title & Community & $\begin{array}{l}\text { Survey } \\
\text { sample }\end{array}$ & $\begin{array}{l}\text { Basic } \\
\text { sample }\end{array}$ \\
\hline$T$ & "General Director & $T$ & - & 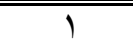 \\
\hline T & $\begin{array}{l}\text { Director of the } \\
\text { Department }\end{array}$ & 9 & $r$ & 0 \\
\hline r & Social workers & $\Lambda V$ & 11 & $0 \leqslant$ \\
\hline$\varepsilon$ & Sports specialists & एะ & $\Lambda$ & 广) \\
\hline - & the total number & $1 \pi$ & YI & NI \\
\hline
\end{tabular}

Analysis of the content of scientific references The content of references $(3,5$, $7,10,11,16)$ was analyzed to identify the new techniques in administrative communication and the researcher used the questionnaire as a data collection tool.

\section{B- Questionnaires:}

The researcher designed a questionnaire form as follows:

Questionnaire: In order to identify the components of administrative communication systems and techniques at the Department of Youth Care, Fayoum University

In order to achieve the goal of the research is to identify the components of systems and techniques of communication management of the Department of Youth Welfare Fayoum University.

1- Identifying the main axes of the questionnaire:

The researcher identified the axes of the form of the systems and techniques of administrative communication at the Department of Youth Welfare Fayoum University in its initial form attached (2) and presented to the experts (9) experts attached (1), Where the researcher resorted to the experts to identify:

-The adequacy and adequacy of the main axes 
-Modify, delete or add other axes

-OK got 3 degrees and not approved one degree
The following table (2) shows the percentage of the consensus agreement on the proposed axes

Table (2)

The frequency and percentage of the axes of the questionnaire $n=9$

\begin{tabular}{|c|c|c|c|c|c|}
\hline Serial & Axis & Agree & $\begin{array}{c}\text { Not } \\
\text { agree }\end{array}$ & Frequency & $\%$ \\
\hline 1 & $\begin{array}{l}\text { Means of } \\
\text { communication used }\end{array}$ & V & r & r & 10.19 \\
\hline$r$ & $\begin{array}{l}\text { Communication } \\
\text { systems }\end{array}$ & $\Lambda$ & 1 & ro & 94.09 \\
\hline$r$ & $\begin{array}{l}\text { Training of } \\
\text { human resources }\end{array}$ & 9 & • & TV & $1 \ldots$. \\
\hline$\xi$ & $\begin{array}{l}\text { Limits of } \\
\text { connections used }\end{array}$ & r & 7 & 10 & 00.07 \\
\hline 0 & $\begin{array}{l}\text { The potential } \\
\text { (human - material) }\end{array}$ & $\Lambda$ & 1 & ro & 94.09 \\
\hline 7 & $\begin{array}{l}\text { Efficient } \\
\text { communication }\end{array}$ & 7 & $r$ & rI & $\vee \vee . \vee \wedge$ \\
\hline V & $\begin{array}{l}\text { Information } \\
\text { Technology }\end{array}$ & $r$ & $\wedge$ & $1 \varepsilon$ & 01.10 \\
\hline $1 \cdot$ & Networks & $\Lambda$ & 1 & ro & 94.09 \\
\hline
\end{tabular}

of the experts on the main axes of the current reality form ranged from $(51.85 \%$ : $100 \%)$. The two axes became axes as follows

-Means of communication used - Communication systems -Training human resources potential (human - physical) -Communication efficiency networks

In the light of the results of the expert opinions on the proposed axes, the researcher studied each axis separately in a detailed study to determine the terms of each axis guided by some scientific references and previous studies on administrative communication systems and techniques.

The questionnaire was prepared in its initial form and Assiut Journal For Sport Science Arts 
then presented to the experts to ensure that:

-Validity of questionnaire as a tool for data collection

-Identify the appropriateness of the proposed phrases for the axes

-Delete or modify the inappropriate statements and Table (3)

Estimated grade and percentage of expert opinions

In terms of the form of the systems and techniques of administrative communication in the Department of Youth Welfare

Fayoum University $(\mathrm{N}=9)$

\begin{tabular}{|c|c|c|c|c|c|c|}
\hline $\begin{array}{c}\text { Netwo } \\
\text { rks }\end{array}$ & $\begin{array}{c}\text { Efficient } \\
\text { communic } \\
\text { ation }\end{array}$ & $\begin{array}{c}\text { Human- } \\
\text { material } \\
\text { potentia } \\
1\end{array}$ & $\begin{array}{l}\text { Traini } \\
\text { ng of } \\
\text { human } \\
\text { resour } \\
\text { ces }\end{array}$ & $\begin{array}{c}\text { Communic } \\
\text { ation } \\
\text { systems }\end{array}$ & $\begin{array}{l}\text { Means of } \\
\text { communic } \\
\text { ation }\end{array}$ & $\begin{array}{c}\text { Ser } \\
\text { ial }\end{array}$ \\
\hline 94.09 & 94.09 & 10.19 & $1 \ldots$ & 10.19 & 10.19 & 1 \\
\hline 10.19 & $1 \ldots$ & $\vee \vee . \vee \wedge$ & 10.19 & 10.19 & 94.09 & $r$ \\
\hline 94.09 & 94.09 & 10.19 & $1 \ldots$ & $1 \ldots$ & $1 \ldots$ & $\mu$ \\
\hline 10.19 & $\vee \vee . \vee \wedge$ & Vマ.VA & 10.19 & 94.09 & $\checkmark \vee . \vee \wedge$ & $\varepsilon$ \\
\hline 94.09 & 10.19 & 10.19 & $1 \ldots$ & 94.09 & $\checkmark \vee . \vee \wedge$ & 0 \\
\hline 94.09 & $\vee \vee . \vee \wedge$ & $\vee \vee . \vee \wedge$ & 94.09 & $1 \ldots$ & $\checkmark \vee . \vee \wedge$ & 7 \\
\hline $1 \ldots$ & 94.09 & 94.09 & $1 \ldots \ldots$ & 10.19 & $1 \ldots$ & V \\
\hline 94.09 & $\vee \vee . \vee \wedge$ & 94.09 & 94.09 & 94.09 & $1 \cdots$ & $\Lambda$ \\
\hline \multirow[t]{8}{*}{$9 r .09$} & $1 \ldots$ & Vマ.VA & 94.09 & $1 \ldots$ & $\vee \vee . \vee \wedge$ & 9 \\
\hline & 94.09 & 94.09 & $1 \ldots$ & 94.09 & 94.09 & 1. \\
\hline & & 94.09 & $1 \ldots$ & 10.19 & 10.19 & 11 \\
\hline & & $1 \cdots$ & & $1 \cdots$ & $1 \cdots$ & $1 T$ \\
\hline & & $1 \cdots \cdots$ & & & 94.09 & $1 \pi$ \\
\hline & & & & & $1 \ldots$ & $1 \varepsilon$ \\
\hline & & & & & 10.19 & 10 \\
\hline & & & & & $\checkmark \vee . \vee \wedge$ & 17 \\
\hline
\end{tabular}

The researcher excluded the words that did not receive the approval rate of $60 \%$ or also add any other proposed words that are not listed in the form.

Table (3) shows the percentage of experts' views on the suitability of the proposed words 
Table (4)

Number of accepted questionnaire statements and deleted phrases after presentation to experts

\begin{tabular}{c|l|c|c|c}
\hline \hline Serial & \multicolumn{1}{|c|}{ Axis } & Total & Deleted phrases & $\begin{array}{c}\text { Acceptable } \\
\text { phrases }\end{array}$ \\
\hline \hline$r$ & $\begin{array}{l}\text { Means of } \\
\text { communication }\end{array}$ & 17 & $\cdot$ & 17 \\
\hline$r$ & $\begin{array}{l}\text { Communication } \\
\text { systems }\end{array}$ & $1 r$ & 1 & 11 \\
\hline$r$ & $\begin{array}{l}\text { Training of } \\
\text { human resources }\end{array}$ & 11 & $r$ & 9 \\
\hline$\varepsilon$ & $\begin{array}{l}\text { Human-material } \\
\text { potential }\end{array}$ & $1 r$ & $\cdot$ & $1 r$ \\
\hline 0 & $\begin{array}{l}\text { Efficient } \\
\text { communication }\end{array}$ & $1 \cdot$ & $r$ & $V$ \\
\hline$\tau$ & Networks & 9 & $r$ & $V$ \\
\hline \hline & Total & $V 1$ & $\wedge$ & $\tau r$ \\
\hline \hline
\end{tabular}

\section{Survey study:}

The

researcher conducted an exploratory study on a sample of the research (10) individuals from outside the survey sample and representative of the original research community and have the same specifications of the original sample during the month of January 2015. The survey aimed to identify the clarity of the questionnaire terms, The results of the survey showed that the questionnaire was appropriate in terms of wording and language and did not show any comments suggesting ambiguity or misunderstanding.
-Scientific transactions for the form of the systems and techniques of administrative communication under the auspices of youth:

-Approved form:

The researcher used the validity of the internal consistency to calculate the truthfulness of the questionnaire in order to verify the validity of the questionnaire. The questionnaire was applied during February 2015 to a group of (21) individuals from the research community and from outside the basic research sample. 
Table (5)

Coefficient between the terms of the first axis (means of communication used) The total axis $(n=2)$

\begin{tabular}{|c|c|c|c|c|c|c|}
\hline Serial & $\begin{array}{c}\text { Means of } \\
\text { communication }\end{array}$ & $\begin{array}{c}\text { Communication } \\
\text { systems }\end{array}$ & $\begin{array}{c}\text { Training } \\
\text { of } \\
\text { human } \\
\text { resources }\end{array}$ & $\begin{array}{l}\text { Human- } \\
\text { material } \\
\text { potential }\end{array}$ & $\begin{array}{c}\text { Efficient } \\
\text { communication }\end{array}$ & Networks \\
\hline 1 & .0 .7 & $\because \vee \mu \wedge$ & .07. & .70. &. $.0 V \mu$ & $.0 \leqslant 0$ \\
\hline$r$ & .791 & $\because V \cdot 7$ & $.0 T$ & $\cdot . \wedge \wedge \Gamma$ & $\cdot V \cdot T$ & $.07 \mathrm{~V}$ \\
\hline$r$ & $.0 \wedge T$ & . हाए & $.07 \varepsilon$ & 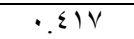 & .OYT & $\cdot \varepsilon \wedge \wedge$ \\
\hline$\varepsilon$ &.$\leqslant r q$ & $.70 \leqslant$ &.$\leqslant 00$ &.$\leqslant T V$ & $\because \leqslant V$. & 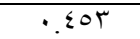 \\
\hline 0 &.$\leqslant .0$ &.$\leqslant \wedge 0$ & $\because \leqslant \leqslant \wedge$ & $.0 \leqslant T$ & $.7+7$ & $.0 \leqslant 1$ \\
\hline 7 &. .704 & $\because$ Vos &. .771 & 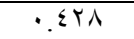 & .019 &. r人o \\
\hline V &.$\leqslant V V$ & .019 & $.0 \mathrm{~V}$. &.$r \wedge V$ & $\because V \leq 0$ & $\because \leqslant 7 r$ \\
\hline$\Lambda$ & .7 .0 & $.0 \wedge$. & .07 & .01. & & \\
\hline 9 & .1990 & .70. & $.0 T$ & .949 & & \\
\hline 1. & $.7 V \cdot$ & $.09 \mathrm{~V}$ & & .70. & & \\
\hline 11 & $\because \vee \wedge T$ & $\because \Sigma Y$. & & $\cdot \wedge \wedge T$ & & \\
\hline IT & $\because 7 \ldots$ & & & $.0 Y \varepsilon$ & & \\
\hline 14 & .077 & & & $.9 \times 7$ & & \\
\hline $1 \leqslant$ & $\because \leqslant \vee 0$ & & & & & \\
\hline 10 & .101 & & & & & \\
\hline 17 & .110 & & & & & \\
\hline
\end{tabular}

The tab value is at the level of $05.0=0.325$

It is clear from Table (5) that the correlation coefficients between the seventh axis and the total sum of the axis ranged from $(0,385: 0,926)$, which are statistically snificant
correlation coefficients at the level of 0,5 , indicating the internal consistency of the axis.

\section{Table (6)}

The correlation coefficients between the sum of each axis and the total sum of the form $(n=21)$

\begin{tabular}{|c|c|c|c|c|}
\hline Serial & Phrase & SMA & $\begin{array}{l}\text { standard } \\
\text { deviation }\end{array}$ & $\begin{array}{c}\text { Calculated } \\
\text { r value }\end{array}$ \\
\hline 1 & Means of communication & $\varepsilon . \cdots r$ & 1.1 .9 & $.7 \cdot V$ \\
\hline r & Communication systems & 1.919 & $1 .+Y \varepsilon$ & .091 \\
\hline$r$ & Training of human resources & $\varepsilon . \wedge \wedge$ & .971 & $.0 \leqslant r$ \\
\hline$\varepsilon$ & Human-material potential & $\varepsilon .1 \cdot 1$ & $1 . \cdots$ & ( \\
\hline 0 & Efficient communication & r.V^o & $1 . \cdots 9$ & $\cdot .7 \cdot r$ \\
\hline 7 & Networks & r.0VI & $1.4 \wedge$ &. .291 \\
\hline
\end{tabular}

The tab value is at the level of $05.0=0.325$ 
Table (6) shows that correlation coefficients between the sum of each axis and the total sum of the form ranged from 0.83: 0.95, which are statistically significant correlation coefficients indicating the internal consistency of the form as a whole -.Stability of the form

The researcher used the method of application and applied the application to calculate the stability coefficient of the questionnaire. The application was applied to 21 individuals from the research community and outside the basic research sample during the second half of February 2015. And then reapplication during the first half of March 2015, with a time interval of (15) days and table (7) shows:

Table (7)

The correlation coefficients between the first and second applicationsA questionnaire for the components of administrative communication systems and techniques and the questionnaire as a whole $(n=21)$

\begin{tabular}{|c|c|c|c|c|c|c|}
\hline \multirow[b]{2}{*}{ Serial } & \multirow[b]{2}{*}{ Axis } & \multicolumn{2}{|c|}{ First app. } & \multicolumn{2}{|c|}{ Second app } & \multirow[b]{2}{*}{$\begin{array}{c}\mathbf{R} \\
\text { value }\end{array}$} \\
\hline & & SMA & $\begin{array}{l}\text { standard } \\
\text { deviation }\end{array}$ & SMA & $\begin{array}{l}\text { standard } \\
\text { deviation }\end{array}$ & \\
\hline 1 & $\begin{array}{l}\text { Means of } \\
\text { communication }\end{array}$ & $\varepsilon \ldots r$ & 1.1 .9 & r.9rᄉ & 1.1. & $\because \times 91$ \\
\hline r & $\begin{array}{l}\text { Communication } \\
\text { systems }\end{array}$ & 7.919 & $1 . T \varepsilon$ & $\leqslant .970$ & $.99 \mathrm{~V}$ & . ATV \\
\hline$r$ & $\begin{array}{l}\text { Training of } \\
\text { human resources }\end{array}$ & $\varepsilon . \wedge \wedge$ & $\cdot .971$ & $\varepsilon . Y \leqslant r$ & $\cdot .9 \wedge 9$ & $\cdot .714$ \\
\hline$\varepsilon$ & $\begin{array}{l}\text { Human-material } \\
\text { potential }\end{array}$ & £.1.1 & $1 \ldots$ & \&.MTV & $1 . I^{\prime}$ & $\cdot \wedge \wedge \mathrm{T}$ \\
\hline 0 & $\begin{array}{l}\text { Efficient } \\
\text { communication }\end{array}$ & r.V^o & $1 . .99$ & r.qAV & $1.1 Y \varepsilon$ & .09. \\
\hline 7 & Networks & $r .0 V 1$ & $1 . r \wedge$ & T.VO\& & $1 . Y$. & $\cdot . \wedge \wedge \mathrm{T}$ \\
\hline
\end{tabular}

The value (t) of the table at the level of significance $(0.05)=0.325$

It is clear from Table (7) that correlation coefficients between the sum of each axis and the total sum of the first application and the second application ranged from (0.590: 0.886) which are statistically significant correlation coefficients at the level of (0.05) indicating the

Assiut Journal For Sport Science Arts 
internal consistency and stability of the questionnaire as a whole.

.TFinalization of the questionnaire

After conducting the scientific procedures of the first questionnaire, verifying the veracity and consistency of the statements. The questionnaire was finalized in annex 3 with 63 words.

Thus, the first questionnaire was applied to the sample of the study in terms of the sample of the questionnaire (81) of the employees of the Department of Youth Welfare Fayoum University, during April and May 2015, according to the balance of the tripartite estimate (OK - to a certain extent). The questionnaire has been corrected so that five (3) and (3) responses have been given (yes) to three degrees and the answer (disagreeing) is one degree and the data has been collected, organized, tabulated and processed statistically.

View and discuss the results:

The researcher will present and discuss the research question. What are the elements and techniques of administrative communication that are currently in the care of Fayoum University and its effectiveness?

\section{Table (8)}

Frequency and percentage of communication axis used

\begin{tabular}{|c|c|c|c|}
\hline Serial & Phrase & Frequency & $\%$ \\
\hline 1 & Electronic notes & TVV & $7 \Lambda . \varepsilon$. \\
\hline$r$ & Bulletin Board & T4 & 19.74 \\
\hline$\mu$ & Letters & rVV & 94.9 \\
\hline$\varepsilon$ & Fax & r9o & $9 . .11$ \\
\hline 0 & Video conferencing & $1 \times 9$ & $\mu .10$ \\
\hline 7 & Meetings & roq & $\Lambda \Lambda . T \varepsilon$ \\
\hline $\mathrm{V}$ & Committees & TAI & 79.41 \\
\hline$\Lambda$ & Conferences & roo & 74.97 \\
\hline 9 & Internal telephone & rol & 1..TV \\
\hline 1. & Mobile & Tr & V9.17 \\
\hline 11 & Administrative decisions & ror & AV.17 \\
\hline IT & Office commands & r^9 & vi.ru \\
\hline $1 T$ & Periodic reports & rAr & 79.11 \\
\hline $1 \varepsilon$ & E-mail & $r \cdot v$ & Vo.A. \\
\hline 10 & what's up & rVT & 9 9..1. \\
\hline 17 & face book & roq & 74.90 \\
\hline
\end{tabular}

Assiut Journal For Sport Science Arts 
Table (8) shows that the percentage of responses of the research sample in the focal point of the means of communication used by the Department of Youth Welfare Fayoum University ranged between (93.09: 31.85)

Where the number (3) was $93.09 \%$, indicating that the traditional communication system, which is still ongoing in the communication systems between the various employees and departments of the Department of Youth Care at Fayoum University.

The number (15) was 92.10, indicating that the research sample preferred using ICT applications in an easy way. This is evident in the use of the Watsab application in administrative work within the Youth Welfare Department at Fayoum University.

While the number (5) received a percentage of 31.85 indicating that the video is not used in the administrative correspondence between the departments and may be due to their presence in the same work location and the high cost of use in that application in correspondence and communication

systems

between departments

The number 16 was 63.95, indicating that the study sample agreed not to use the Facebook application to communicate between the different departments of the Youth Welfare Department.

The purpose of this application is social communication among individuals rather than using it in communication between departments and employees. .

The study of Ali Hassan AlShihri (2005) 11 emphasizes the necessity of providing Internet networks to all employees in order to provide e-mail and e-mail to all employees and facilitate the use of e-mail for all employees of the institution to provide financial and material resources in the use of paper and mail.

While Abdul Majeed Abdul Mohsen Mohammed (2011) (10) points out the need to provide the environment for the use of electronic correspondence from computers and the Internet and human elements are aware of how to use computers well and suitable for the nature of work. 
Table (9)

Frequency and percentage axis communication systems

\begin{tabular}{|c|c|c|c|}
\hline Serial & Phrase & Frequency & $\%$ \\
\hline$\overline{1}$ & $\begin{array}{l}\text { Modern technological processes help to } \\
\text { exchange ideas and information among the } \\
\text { staff of the University's Youth Welfare } \\
\text { Department }\end{array}$ & r人o & 90.7 \\
\hline$r$ & $\begin{array}{l}\text { An information system is available to all users } \\
\text { of youth care services - students, staff, faculty } \\
\text { members }\end{array}$ & r7q & $77 . \leqslant Y$ \\
\hline$r$ & $\begin{array}{l}\text { Information systems processes help to transfer } \\
\text { information between different functional } \\
\text { levels of the Youth Welfare Department }\end{array}$ & MTV & $9 . .74$ \\
\hline$\varepsilon$ & $\begin{array}{l}\text { IT processes help ease and track decisions and } \\
\text { administrative orders between different } \\
\text { university faculties and the Youth Welfare } \\
\text { Department }\end{array}$ & 490 & $9 V .04$ \\
\hline 0 & $\begin{array}{l}\text { The current information systems are in line } \\
\text { with the existing administrative requirements } \\
\text { of the Youth Welfare Department of the } \\
\text { University }\end{array}$ & TrV & ON.OY \\
\hline 7 & $\begin{array}{l}\text { Human factors are available to handle all MIS } \\
\text { devices }\end{array}$ & r90 & $9 V .04$ \\
\hline V & $\begin{array}{l}\text { A confidential level of all administrative } \\
\text { information is available between the } \\
\text { functional levels of the Youth Welfare } \\
\text { Department }\end{array}$ & TVV & 94.9 \\
\hline$\Lambda$ & $\begin{array}{l}\text { Communication systems are currently helping } \\
\text { to accomplish all tasks as quickly as possible }\end{array}$ & rᄉI & $9 \leq . \cdot V$ \\
\hline 9 & $\begin{array}{l}\text { Communication systems are in line with } \\
\text { decision-making policies of the Youth } \\
\text { Welfare Department }\end{array}$ & rAT & $79 . \wedge 1$ \\
\hline 1. & $\begin{array}{l}\text { The staff of the Youth Welfare Department } \\
\text { uses communication systems to service } \\
\text { administrative processes within youth care }\end{array}$ & rol & 1.. $T \mathrm{~V}$ \\
\hline 11 & $\begin{array}{l}\text { There are electronic channels } \\
\text { communication between all employees } \\
\text { various youth welfare departments }\end{array}$ & אדו & $7 \leq .9 \leq$ \\
\hline
\end{tabular}

Table (9) shows that the

systems at the Department of percentage of responses of the research sample in the focal point of communication

Youth Welfare Fayoum

University ranged between (97.53: 58.52). 
( 7 ، )scored 97.53 percentage points, indicating that the study sample agreed on the ease of tracking electronic correspondence and how quickly the employees respond to such correspondence in the light of information technology. This is used in how to make administrative decisions and evaluate administrative processes within university faculties. With the presence of human elements that can deal with modern technology in various administrative processes.

The number (1) was $95.06 \%$, indicating that the study sample agreed to benefit from the introduction of modern technology in the administrative processes within the Youth Welfare Department and to provide a lot of time and effort in accomplishing the tasks such as using computer, Alexandria, Aldata Shaw and most importantly internet and e-mail in sending and receiving Admin scripts do not bother to go and get them.

While the number (11) received 64.94 percent indicating that there are no open channels of communication between all the workers. This may be due to the weakness of the material resources currently available, limited to some basic elements of the use of information technology, and the difficulty of getting all the information at the same time for all Employees of the Youth Welfare Department.

The number (2) was $66.42 \%$, indicating that there is no database for all youth care services beneficiaries in the full form of communication with them. This is due to the lack of designing electronic database programs which are managed for all administrative and technical studies for the management of youth care. Students, faculty members, university faculties, sports union of universities and other bodies that cooperate with the Youth Welfare Department

Jassem Mohammed AlHamdan and Fahad Al-Eneizi (2008) emphasize the need of senior management to provide electronic management requirements for the administrative processes of the organization in light of its needs and various electronic transactions.

The study of the increase Saad Jubeir Al-Matrafi (2012) (5) on the pursuit of senior 
management to provide electronic channels of communication between all employees of the institution of Internet networks and modern

electronic devices in order to provide the appropriate environment for communication systems.

Table (10)

Frequency and percentage of human resources training focus

\begin{tabular}{|c|c|c|c|}
\hline$\overline{\text { Serial }}$ & Phrase & Frequency & $\%$ \\
\hline 1 & $\begin{array}{l}\text { Training programs on information and } \\
\text { communication systems are available } \\
\text { at the Youth Welfare Department }\end{array}$ & r & $9 . .15$ \\
\hline r & $\begin{array}{l}\text { Employees are selected for training } \\
\text { courses based on personal experience }\end{array}$ & rтq & $77 . \leqslant Y$ \\
\hline r & $\begin{array}{l}\text { Employees are selected for training } \\
\text { courses based on the principle of } \\
\text { efficiency in work }\end{array}$ & TVO & $7 V .9$. \\
\hline$\varepsilon$ & $\begin{array}{l}\text { Employees are selected for training } \\
\text { courses to raise the level of work } \\
\text { performance of the Youth Welfare } \\
\text { Department }\end{array}$ & roo & AV. 70 \\
\hline 0 & $\begin{array}{l}\text { Training courses for communication } \\
\text { systems are commensurate with the } \\
\text { level of staff capacity of the Youth } \\
\text { Welfare Department }\end{array}$ & rVI & 91.7. \\
\hline 7 & $\begin{array}{l}\text { There is an annual plan for the extent } \\
\text { of the needs of workers from courses } \\
\text { of communication systems and } \\
\text { techniques }\end{array}$ & r & $9 V . \varepsilon$ \\
\hline V & $\begin{array}{l}\text { The level of training courses for staff } \\
\text { of the Youth Welfare Department is } \\
\text { being upgraded }\end{array}$ & TrV & $\Lambda \cdot . \vee \leqslant$ \\
\hline$\wedge$ & $\begin{array}{l}\text { Employees who pass the training } \\
\text { courses are motivated by excellence }\end{array}$ & $r \varepsilon$ & $\wedge \leq . Y$. \\
\hline 9 & $\begin{array}{l}\text { The budget allocated for the training } \\
\text { courses is commensurate with the } \\
\text { actual needs }\end{array}$ & M10 & $\vee V . \vee \wedge$ \\
\hline
\end{tabular}

Assiut Journal For Sport Science Arts 
It is clear from Table (10) that the percentage of responses of the research sample in the human resource training course at the Department of Youth Welfare Fayoum University ranged between (97.04: 66.42).

Where the number (6) was obtained at $97.04 \%$ indicating the agreement of the sample of the study on the existence of an annual plan for the training programs and training needs of the Youth Welfare Department, which is accredited by the information network in the university and the participation of its employees according to the actual need of these training courses in the field of communications systems and technologies How to use email, internet or software related to the university network.

( $\left.{ }^{\circ}\right)$ received

91.60 percentage points, indicating that the training courses for the communications systems are suitable for the level and abilities of the employees of the Youth Care Department in order to make the most of the human potential available to the employees of the Youth Welfare Department.
While the number (2) obtained a percentage of 66.42 indicating that the sample did not agree on the methods of selection of employees for training courses. There is a kind of administrative bias among some managers of youth welfare departments and their selection of some specialists without others without specific criteria in the nomination of specialists for these training programs

This confirms that clause (3) stands at 67.90 to agree with the second clause that there are no criteria for selecting specialists for electronic courses and programs.

The study of Rehab Sayed Mabrouk (2012) (6) emphasizes the requirements of the quality of administrative operations, providing adequate material and human resources and providing training programs for information and communication systems within the institution.

The study of Mohamed Ali Al Mana (2006) (15) indicates the need for the senior management to work out an annual plan within the proposed project of the institution, which includes all 
the training courses for employees in the different sector in the institution and in view of the needs of the institution of courses in the field of work.

\section{Table (11)}

Frequency and percentage of potential (human)

\begin{tabular}{|c|c|c|c|}
\hline Serial & Phrase & Frequency & $\%$ \\
\hline $\bar{T}$ & $\begin{array}{l}\text { The staff of the Youth Welfare } \\
\text { Department have the ability to use } \\
\text { computers }\end{array}$ & rᄉr & $9 \leq .0 \mathrm{~V}$ \\
\hline$r$ & $\begin{array}{l}\text { The staff of the Youth Welfare } \\
\text { Department have the ability to use } \\
\text { various Internet applications and } \\
\text { programs }\end{array}$ & $r \leqslant 1$ & $\wedge \Sigma .,$. \\
\hline$r$ & $\begin{array}{l}\text { The staff of the Youth Welfare } \\
\text { Department have the ability to use } \\
\text { Office programs }\end{array}$ & r90 & $V Y . \wedge \varepsilon$ \\
\hline$\varepsilon$ & $\begin{array}{l}\text { The staff of the Youth Welfare } \\
\text { Department have the ability to store } \\
\text { and retrieve data in a timely manner }\end{array}$ & qu & Nז.V. \\
\hline 0 & $\begin{array}{l}\text { There is an e-mail for all employees } \\
\text { of the Youth Welfare Department }\end{array}$ & $r \leq 1$ & 09.01 \\
\hline 7 & $\begin{array}{l}\text { The youth care management staff } \\
\text { maintains the level of protection } \\
\text { required for different computers }\end{array}$ & rol & 71.91 \\
\hline V & $\begin{array}{l}\text { There is a sub-department specialized } \\
\text { in computers within the care of youth }\end{array}$ & 1) & $r \cdot \ldots$ \\
\hline $\begin{array}{l}\text { the per } \\
\text { the res } \\
\text { center } \\
\text { the D } \\
\text { Welfare } \\
\text { ranged } \\
\text { Where } \\
\text { a pe } \\
\text { indicati } \\
\text { study s }\end{array}$ & $\begin{array}{l}\text { Table (11) shows that } \\
\text { centage of responses of } \\
\text { search sample in the } \\
\text { of potential (human) in } \\
\text { epartment of Youth } \\
\text { e Fayoum University } \\
\text { between ( } 94.57: 20.00) \\
\text { the phrase (1) received } \\
\text { rcentage of 94.57, } \\
\text { ing the agreement of the } \\
\text { ample on the possibility }\end{array}$ & $\begin{array}{l}\text { ng the } \\
\text { of number } \\
\text { rcent, indic } \\
\text { of the emp } \\
\text { of applicat } \\
\text { in the Inter } \\
\text { ent of admi } \\
\text { under }\end{array}$ & $\begin{array}{l}\text { modern } \\
\text { computer } \\
\text { 2) scored } \\
\text { ating the } \\
\text { loyees in } \\
\text { ions and } \\
\text { het in the } \\
\text { nistrative } \\
\text { the }\end{array}$ \\
\hline
\end{tabular}


management of youth care at Fayoum University.

While the number (7) was $20.00 \%$, indicating that the study sample agreed that there is no computer administration within the functional structure of the Youth Welfare Department, which has the jurisdiction of periodic monitoring of computers and permanent maintenance.

The number (5) is 59.51, indicating that there is no email for all employees of the Youth Welfare Department. This is done through the e-mail of each department separately and the director of administration without workers. There must be an e- mail for all employees They have everything that is specific to their management from decisions or administrative decisions. This will provide a lot of effort, time, money and ease of access to all parties to the administrative process without any trouble.

The study of Magdy Abdel-Basir Awad (2004) (14) emphasizes the need to provide specialized management of information systems, which has the functions of periodic monitoring of all electronic devices, periodic maintenance and electronic protection programs and levels of protection for computers.

\section{Table (12)}

Frequency and percentage of potential (physical)

\begin{tabular}{|c|c|c|c|}
\hline$\overline{\text { Serial }}$ & Phrase & Frequency & $\%$ \\
\hline $\bar{\Lambda}$ & $\begin{array}{l}\text { A computer is available for all } \\
\text { employees of the University's Youth } \\
\text { Welfare Department }\end{array}$ & ror & $T r . \leqslant V$ \\
\hline 9 & $\begin{array}{l}\text { A computer is available for all } \\
\text { employees of the University's Youth } \\
\text { Welfare Department }\end{array}$ & 109 & Tq.Y \\
\hline 1. & $\begin{array}{l}\text { Printers and Scanner are available } \\
\text { from the Youth Care Department }\end{array}$ & rAq & דוr \\
\hline 11 & $\begin{array}{l}\text { Senior management provides the } \\
\text { required resources as much as possible }\end{array}$ & rql & 97.05 \\
\hline Ir & $\begin{array}{l}\text { There are specialized programs in the } \\
\text { management and operation of the } \\
\text { Youth Welfare Department }\end{array}$ & 11 & $r \cdot \ldots$ \\
\hline$\pi$ & $\begin{array}{l}\text { There are engineers to follow up the } \\
\text { maintenance of computers periodically }\end{array}$ & Y10 & or.. 9 \\
\hline & Assiut Journal For Sport Science Arts & & \\
\hline
\end{tabular}


It is clear from Table (12) that the percentage of responses of the research sample in the center of potential (physical) of the Department of Youth Welfare Fayoum University ranged between (96.54: 20.00)

(1) received a percentage of 96.54 which indicates that the senior management provide the required capabilities of computers, printers and Alexandria according to the material conditions of the Department of Youth Welfare according to the financial allocations within the university budget.

The number (10) was 71.36, indicating that the study sample agreed to some extent on the provision of auxiliary electronic equipment for the implementation of administrative operations as soon as possible and limited to a printer for each department.

While the number received $20.00 \%$ indicating that there are no technological programs within the Youth Welfare Department and their reliance on correspondence and paper correspondence.

The number 9 is 39.26 , indicating that the study sample agreed that there is no internet network open to all employees of the Youth Welfare Department and limited to desktop computers only. This may be due to the weakness of the technological structure of the Youth Welfare Department.

The study of both Musab Ismail Tabash (2008) 16 and Fawaz Yassin Harhasha (2009) (12) confirms the necessity of providing the basic components of the ICT components from computers, internet networks, electronic programs and e-mail, with levels of confidentiality of incoming and outgoing information From different departments.

Table (13)

Frequency and percentage axis of communication efficiency

\begin{tabular}{|c|c|c|c|}
\hline Serial & Phrase & Frequency & $\%$ \\
\hline 1 & Computers are regularly maintained & 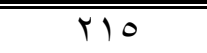 & or..9 \\
\hline r & $\begin{array}{l}\text { Computer hardware helps employees } \\
\text { save time, effort and cost }\end{array}$ & rvi & 91.7. \\
\hline$r$ & $\begin{array}{l}\text { There are confidential levels of } \\
\text { information received and received by } \\
\text { the Youth Welfare Department }\end{array}$ & V & NT.r \\
\hline
\end{tabular}


FollowTable (13)

Frequency and percentage axis of communication efficiency

\begin{tabular}{|c|c|c|c|}
\hline Serial & Phrase & Frequency & $\%$ \\
\hline$\varepsilon$ & $\begin{array}{l}\text { There are administrative levels to } \\
\text { certify administrative decisions within } \\
\text { the Youth Welfare Department }\end{array}$ & س人ז & $9 \leqslant .0 V$ \\
\hline 0 & $\begin{array}{l}\text { The Director can follow up the level of } \\
\text { completion of the Youth Care Department } \\
\text { at any time }\end{array}$ & ror & NV.17 \\
\hline 7 & $\begin{array}{l}\text { There is a user name and password for all } \\
\text { computers in the Youth Care Department }\end{array}$ & $1 V T$ & $\varepsilon Y . V Y$ \\
\hline V & $\begin{array}{l}\text { There is an e-mail for all employees of } \\
\text { the Youth Welfare Department }\end{array}$ & IVV & $\varepsilon r . V$. \\
\hline
\end{tabular}

Table (13) shows that the percentage of responses of the research sample in the field of communication efficiency at the Department of Youth Welfare Fayoum University ranged between (94.57: 53.09)

Where the number (4) obtained a percentage of 94.57 indicating the existence of administrative levels within the Department of Youth Welfare to ratify the administrative decisions by the level of career within the Department of Youth Welfare.

The number (2) obtained 91.60 percent, indicating the approval of the study sample on the importance of computers and the Internet in providing a lot of time, effort and cost, and consequently increase the productivity of the work in the Department of Youth Welfare

The number (3) was 83.21, indicating that the sample of the study agreed to the existence of levels of confidentiality of information issued by Al-Wadra for the management of youth care. This is due to the existence of job levels within the Youth Welfare Department and the existence of some decisions with secret levels. To study the type and size of the information available to them according to the level of career and to establish a logical basis and a process of deliberate levels of confidentiality and according to the requirements of the need and work in a form that constitutes a reasonable and acceptable classification 
does not affect the level of completion of work and tasks and at the same time does not pose a threat and threat For the administrative operations of the Youth Welfare Department.

The study of Ali Hassan alShihri (2005) (11) on the need to provide a user name and password for all the computers in the Authority to provide a level of protection of information contained in the computers from theft and the provision of e-mail to all employees of the Commission to follow up the incoming messages as soon as possible As soon as they are issued.

\section{Table (14)}

Frequency and percentage of network hub

\begin{tabular}{|c|c|c|c|}
\hline Serial & Phrase & Frequency & $\%$ \\
\hline 1 & $\begin{array}{l}\text { There is an e-mail for all employees of } \\
\text { the Youth Welfare Department }\end{array}$ & roo & NV.70 \\
\hline r & $\begin{array}{l}\text { Employees are able to use computers } \\
\text { with high efficiency }\end{array}$ & 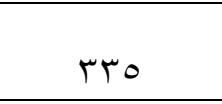 & Ar.VT \\
\hline$r$ & $\begin{array}{l}\text { There is a horizontal and vertical } \\
\text { communication network for all } \\
\text { employees within the Youth Welfare } \\
\text { Department }\end{array}$ & rar & VT. TO \\
\hline$\varepsilon$ & $\begin{array}{l}\text { The Internet is used to provide better } \\
\text { services to workers and beneficiaries } \\
\text { of youth care services }\end{array}$ & rrq & NI.Y \\
\hline 0 & There is an online youth care website & TAV & $\overline{V \cdot . \wedge T}$ \\
\hline 7 & $\begin{array}{l}\text { Wi-Fi networks are located within the } \\
\text { Youth Welfare Department }\end{array}$ & 八) & $r \cdot . \cdot$ \\
\hline V & $\begin{array}{l}\text { There are enough computers within } \\
\text { the Youth Welfare Department }\end{array}$ & rva & 94.01 \\
\hline
\end{tabular}

Table (14) shows that the percentage of responses of the research sample in the center of communication networks at the Department of Youth Welfare Fayoum
University ranged between (93.58: 20.00(

(v) scored

$93.58 \%$ indicating that there are central computer systems within each of the departments of youth care at Fayoum University. 
This is considered one of the basic requirements in providing the appropriate technological environment and working on how to use it in the most complete manner. Upgrading the administrative processes within the youth welfare at Fayoum University

The number (1) is 87.65 percent, indicating that there is an Internet network within the Youth Welfare Department, but not fully in terms of providing more Internet points for youth care workers.

The number (5) was 70.86 percent, indicating that there is an electronic page within the university site, which presents the job structure of the Youth Welfare Department, objectives, vision and policies within the Youth Welfare Department.

While the number (6) obtained $20.00 \%$. This indicates that the study sample agreement indicates that there is no Wi-Fi network within the Youth Welfare Department. This may be due to the misuse of the internet in the working hours and the lack of internet access on the computers located in the youth welfare departments.
The study of Rehab Sayed Mabrouk (2012)

emphasizes the necessity of having a website to communicate with beneficiaries and service providers in order to provide the best environment for communication with them and the presence of some obstacles in the misuse of the Internet during work.

\section{Conclusions:}

-The development of communication techniques increases the performance rates of workers in the care of young people.

-There is no e-mail for all employees of the Youth Welfare Department

-Dependence

on

administrative letters paper more than the use of e-mail

-There is no management of information and communication systems that follow the Youth Welfare Department at the university

-Few computers exist in the administration of youth care and affiliated departments

-Using the Internet during work time wrongly

-Ability of employees to use computers properly 
-Lack of specialized training courses to improve the level of use of modern technology

-Weak budget allocated for the modernization of computers in the management of youth care

\section{Recommendations:}

1- The need to use communication techniques within the Youth Welfare Department appropriately.

2-Providing financial support for the continuous updating of programs and electronic devices

3- Provide appropriate training courses and programs to use youth care communication techniques

4-Seeking an e-mail for all employees of the Youth Welfare Department, sending correspondence and administrative letters and limiting paper correspondence whenever possible.

5- Management of a unit for information systems and communication techniques within the functional structure of youth care.

\section{References}

\section{1- Abdel Hamid Abdel} Fattah El Maghraby: Management Information Systems- Principles and Principles, Mansoura, Dar AlHarith, 2002

\section{2- Abdul Majid Abdel-} Mohsen

Mohamed:

"Obstacles to administrative communication affecting the performance of workers in the passports of Riyadh City, Faculty of Graduate Studies, Naif Arab University for Security Sciences, Riyadh, 2011

\section{3-Ali Hassan Al-Shahri:}

"Administrative Communication and its Role in Job Performance from the Perspective of Criminal Security Associates in Riyadh City", unpublished Master Thesis, Riyadh, Naif Arab University for Security Sciences, 2005.

4- Bachir Kaouja: The Role of Information and Communication Technologies in Improving Internal Communication in Algerian Public Hospitals (Case Study of Mohamed Boudiaf Borgala Hospital), Faculty of Economic and Commercial Sciences and Sciences of Al-Tayseer University, Qusada Mrabah, Urgla_2013.

\section{5- Bawaitit Jalaluddin:} organizational communication and its relation to job performance, a field study on the implementing workers in the Foundation Sonalgaz, Annaba, 2009 
6- Fawaz Yassin Harhasha: "The degree of administrative communication with school principals from the point of view of teachers in the city of Irbid," published research, Journal of Human Sciences, No. 42, 2009.

7- Gamal Mohamed Jalal: Constraints on the Use of Computer and Information Systems in Sports Clubs in the Arab Republic of Egypt, Unpublished Master Thesis, Faculty of Physical Education, Helwan University, Cairo, 2002.

8- Ganby ,I lhon, The organizational communication . process in schools, educational sciences : The ory and practice , V7 np 787- 798 may (2007).

9- Jassem Mohammed AlHamdan, Fahad Mayouf AlEnezi: "Electronic Management in the Administrative Communication Process in Primary Schools in the State of Kuwait (its Importance, Impediments, and Proposals)", Journal of Gulf Message, No. 15, 2008.

10. Kamal Abdulrahman Darwish, Mohamed Sobhy Hassanein: "The Encyclopedia of Vector Sports Management at the Beginning of the New Century (Volume III), Marketing and Modern Communication and the Dynamics of Human Performance in Sport Management", 1, Dar Al-Fikr Al-Arabi, Cairo, 2004.

\section{Majdi Abdelbasir Awad:} "Modernization of communication systems and its impact on the performance of the administrative apparatus in the Arab Republic of Egypt,

12- Nakpodia, E. D. : The Influence of Communication on Administration of Secondary Schools in Delta State, Nigeriaî, International NGO Journal Vol. 5(8), (pp. 194-198) (2010) (http:// www.academicjournals.org/IN GOJ).

13-Rehab Sayed Mabrouk: Imagine a proposal for quality of job performance using information technology in the staff of the departments of youth and sports in some governorates of Upper Egypt, Master Thesis, Faculty of Physical Education, Assiut University, 2012 
14- Samer Abdul-Jameed Al-

Bashashah: The Effect of the

Quality of Management Information Systems in Raising the Level of Job Performance in the Jordanian Social Security Institution. Field Study, Journal of Accounting, Administration and Insurance, Faculty of Commerce, Cairo University, No. 205, 2005.

15- Sayed Gad El-Rab: Recent Trends in Human
Resource Management, Friends Library, 1 st, 2008.

\section{6- Ziad Saad Jubair Al-}

Murtafi: Effectiveness of administrative communication methods and obstacles in the principals of primary schools in the city of Mecca from the point of view of teachers, Master Thesis, Faculty of Education, Umm Al-Qura University, Saudi Arabia, 2012. 